Acta vet. scand. $1986,27,11-22$.

From the Department of Pathology, Norwegian College of Veterinary Medicine, Oslo, Norway.

\title{
IDENTIFICATION OF TOXOPLASMA GONDII AND ENCEPHALITOZOON CUNICULI BY IMMUNOPEROXIDASE TECHNIQUES AND ELECTRON MICROSCOPY, IN STORED, FORMALIN-FIXED, PARAFFIN-EMBEDDED TISSUE
}

\author{
By \\ Inge Bjerkås and Thor Landsverk
}

\begin{abstract}
BJERKÅS, I. and T. LANDSVERK: Identification of Toxoplasma gondii and Encephalitozoon cuniculi by immunoperoxidase techniques and electron microscopy, in stored, formalin-fixed, paraffin-embedded tissue. Acta vet. scand. 1986, 27, 11-22. - The peroxidase-antiperoxidase (PAP), avidin-biotin-complex (ABC) techniques, and electron microscopy, were used to identify protozoan parasites in formalin-fixed material from routine necropsy cases. The material comprised paraffin blocks, that had been stored for up to 18 years, from 18 cases of suspected toxoplasmosis and encephalitozoonosis. With the ABC method a higher dilution of primary antibody could be used than with the PAP method. However, with both methods, a distinct reaction occurred with appropriate dilutions. The age of the material did not seem to effect the result. Frequently, phagocytized and necrotic parasites were also stained. Cystozoites (bradyzoites) of $T$. gondii were stained faintly compared to the endozoites (tachyzoites). A Toxoplasma-like parasite from a dog did not react with anti-Toxoplasma serum, and ultrastructurally it proved to be consistent with an unidentified cyst-forming sporozoan parasite previously reported in dogs. Electron microscopy based on paraffin-embedded tissue, seems to be a valuable method for identification of protozoan parasites, and thus provide a supplement or alternative to the immunoperoxidase methods.
\end{abstract}

protozoan parasites; histologic identification; i m mu ohistochemistry; ultrastructure.

The advent of immunoperoxidase methods, and in particular, the most sensitive peroxidase-antiperoxidase (PAP) (Sternberger et al. 1970) and avidin-biotin-complex (ABC) methods (Guesdon et al. 1979, Hsu et al. 1981, Wood \& Warnke 1981) has drama- 
tically increased the possibility of establishing an etiological diagnosis in infectious disorders when only formalin-fixed tissue is available. This is relevant in connection with, for example, disorders due to protozoan parasites which are often difficult to demonstrate in sections treated by conventional histologic methods, either because the parasites are present only in small numbers in the sections, or because the parasites are difficult to distinguish from other structures. Likewise, in many cases identification of protozoa cannot be made solely on the basis of the light microscopic appearance.

Though Andres et al. (1981) and Dutton et al. (1984) were successful in applying the PAP method in toxoplasmosis, so far only limited efforts have been made to employ the new immunoperoxidase methods for the detection of other protozoan parasites. Apparently, no retrospective studies have hitherto been reported, and consequently little is known about the stability of protozoan antigens after storage in paraffin-embedded tissue, the usual means of storage practised in histologic laboratories.

Electron microscopy represents an alternative method for diagnosis when formalin-fixed tissue is available (Scholtyseck \& Mehlhorn 1970, Sulzer et al. 1979), but reports on the fitness of paraffin-embedded and even stored tissue, for fine-structural identification of protozoan parasites, are apparently lacking.

This paper reports a retrospective study in which the PAP and $A B C$ techniques were applied in demonstrating and identifying $\mathbf{T}$. gondii and $\mathrm{E}$. cuniculi in histologic sections from routine necropsy material. In addition, the identity of the parasites was confirmed by electron microscopic examinations based on deparaffinized material.

\section{MATERIALS AND METHODS}

The examinations were based on paraffin-embedded, formalin-fixed tissue from routine necropsy cases, in which Toxoplasma-like or Encephalitozoon-like structures were demonstrated in histologic sections.

\section{Toxoplasmosis}

Cases of suspected toxoplasmosis included cats, hares, blue foxes, and a dog (Table 1). The sections from the hares were obtained from the Department of Wildlife Diseases, the National 
Veterinary Institute, Oslo. The sections from the foxes were obtained from the Regional Veterinary Laboratory in Bergen. Liver sections from mice inoculated intraperitoneally or subcutaneously with the RH-strain of $\mathbf{T}$. gondii, served as positive controls.

\section{Encephalitozoonosis}

The cases of suspected encephalitozoonosis included young blue foxes and a rabbit (Table 1) in which Encephalitozoon-like structures were stained by the modified Gram method (Petri 1969). The positive controls were spontaneous cases exhibiting a great number of parasites, which were identified on the basis of ultrastructural criteria in material fixed immediately post mortem in $3 \%$ buffered glutaraldehyde.

Tab le 1. Case material.

\begin{tabular}{|c|c|c|c|c|}
\hline $\begin{array}{l}\text { Case } \\
\text { no. }\end{array}$ & $\begin{array}{l}\text { Host } \\
\text { species }\end{array}$ & $\begin{array}{c}\text { Year of } \\
\text { necropsy }\end{array}$ & $\begin{array}{l}\text { Immunoperoxidase } \\
\text { studies }\end{array}$ & $\begin{array}{l}\text { Electron } \\
\text { microscopic } \\
\text { studies }\end{array}$ \\
\hline \multicolumn{5}{|c|}{ Toxoplasma-like parasites } \\
\hline 1 & Cat & 1968 & Brain & Brain \\
\hline 2 & Cat & -84 & Myocardium, liver & Myocardium \\
\hline 3 & Dog & -67 & Brain, spinal cord & Spinal cord \\
\hline 4 & Blue fox & -84 & Kidney, lung & Kidney \\
\hline 5 & , , , & -84 &,$\quad$, & - \\
\hline 6 & Hare & -80 & Liver & Liver \\
\hline 7 & , & -80 & ” & , \\
\hline 8 & , & -80 & 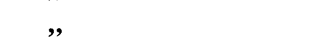 & - \\
\hline 9 & , & -82 & , & - \\
\hline 10 & $"$ & -82 & " & - \\
\hline 11 & , & -82 & 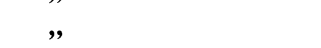 & Liver \\
\hline 12 & , & -82 & ” & - \\
\hline \multicolumn{5}{|c|}{ Encephalitozoon-like parasites } \\
\hline 13 & Blue fox & 1982 & Brain, kidney & Kidney \\
\hline 14 & ,, & -82 & Brain, kidney & Brain \\
\hline 15 & $” \quad$, & -82 & Kidney & - \\
\hline 16 & $" \quad$, & -82 & 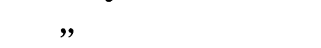 & - \\
\hline 17 &, & -78 & 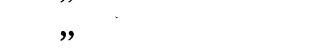 & - \\
\hline 18 & Rabbit & -78 & , & - \\
\hline
\end{tabular}

\section{Immunoperoxidase methods}

The specific rabbit anti-Toxoplasma serum, produced by inoculation of endozoites (tachyzoites) of the RH-strain, was 
obtained from the Norwegian Defence Microbiological Laboratory, Oslo. The rabbit anti-Encephalitozoon serum was obtained from Testman A/S, Uppsala, Sweden). The PAP reagents (swine anti-rabbit antibody, horseradish peroxidase, and rabbit antihorseradish peroxidase antibody) were obtained from Dakopatts A/S, Copenhagen, Denmark. Vectastain ${ }^{\circledR}$ ABC Kit (Vector Laboratories, Burlingame, California, USA) was used when applying the $\mathrm{ABC}$ technique.

P A P m e thod. The sections were cut at about $4 \mu \mathrm{m}$ and placed for $30 \mathrm{~min}$ in an oven at $60^{\circ} \mathrm{C}$. The sections were immediately transferred to a fresh xylene bath, and then hydrated in graded alcohols. The rehydrated sections were incubated for 30 min with $3 \%$ hydrogen peroxide in methanol, in order to inactivate endogenous peroxidases. They were then immersed for $20 \mathrm{~min}$ in phosphate-buffered saline (PBS: $137 \mathrm{mmol} / \mathrm{l}$ sodium chloride, $2.7 \mathrm{mmol} / \mathrm{l}$ potassium chloride, $1.5 \mathrm{mmol} / \mathrm{l}$ potassium dihydrogen phosphate, $8 \mathrm{mmol} / \mathrm{l}$ disodium hydrogen phosphate2-hydrate) $\mathrm{pH} \mathrm{7.3,} \mathrm{and} \mathrm{incubated} \mathrm{for} 20 \mathrm{~min}$ with dilute normal swine serum to prevent non-specific background staining. Excess serum was blotted up around the sections. The sections were subsequently subjected to the following step-wise procedure; incubation for $30 \mathrm{~min}$ with the primary antiserum diluted in PBS, washing for $10 \mathrm{~min}$ in $\mathrm{PBS}$, incubation for $30 \mathrm{~min}$ with dilute swine anti-rabbit serum (1:40), washing in PBS, incubation for 20 min with peroxidase-antiperoxidase complex, washing in PBS, and then in Tris-maleic buffer (200 mmol/l Tris(hydroxymethyl)-aminomethane, $200 \mathrm{mmol} / \mathrm{l}$ maleic acid) $\mathrm{pH}$ 7.2 , incubation for $10 \mathrm{~min}$ with enzyme substrate $\left(0.5 \mathrm{mg} 3.3^{\prime}\right.$ diaminobenzidin-4HCl per $\mathrm{ml}, 0.01$ fresh solution of $1 \%$ hydro-

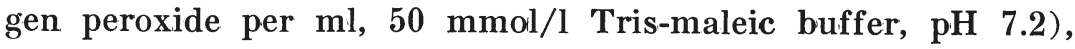
washing for 5 min with distilled water, and counterstaining for 2 min with hematoxylin. The sections were finally mounted in glycerin jelly.

A B C $\mathrm{m}$ e $\mathrm{th}$ od. The test was performed according to the procedure stated by the manufacturer (Vector Laboratories). In this procedure, normal goat serum was used to prevent nonspecific background staining. After the incubation with primary antisera for $30 \mathrm{~min}$, the sections were washed in PBS and incubated for 30 min with diluted biotinylated goat antibody to rabbit immunoglobulins. After washing in PBS, the sections were 
incubated for 30 min with peroxidase conjugated biotin-avidin complex. The sections were then washed in PBS and Tris-maleic buffer and substrate solution was applied.

Control sections were included in which the primary rabbit antiserum was replaced by normal rabbit serum.

\section{Ultrastructural studies}

Tissue from most of the cases (Table 1) was prepared for electron microscopy. A small piece of tissue, corresponding to an area containing parasitic structures in the light microscopic sections, was cut out of the paraffin block. The tissue was deparaffinized, rehydrated in alcohols, post-fixed in osmium tetroxide, dehydrated in alcohols, and embedded in Epon. Semithin sections were stained with toluidine blue. Ultra-thin sections were stained with uranyl acetate and lead citrate.

\section{RESULTS}

\section{Immunoperoxidase studies}

Both in cases of suspected toxoplasmosis and encephalitozoonosis a distinct brown staining occurred when specific antisera were used. At optimal dilutions of primary antisera, background staining was minimal both with the PAP and $A B C$ method. However, the ABC method was more sensitive than the PAP method. The age of the paraffin blocks did not seem to affect the results.

Toxoplasma-like parasites. In all cases except in the dog (Case 3), parasites were stained when anti-Toxoplasma serum was used as primary antiserum (Figs. 1, 2 and 3). The zoites were stained brown, with an even more distinct brown rim at the periphery, emphasizing the shape of the parasites. Endozoites were always strongly stained, and a staining along the membrane of the parasitophorous vacuole usually being observed. In addition, necrotic material and structures in the cytoplasm of macrophages were sometimes stained. However, there was no reaction when normal rabbit serum or anti-Encephalitozoon serum was used as primary antiserum. In the mice (control cases) and the hares (Cases 6-12), only endozoites were observed. Autolytic changes were relatively prominent in some of the hares, and endozoites could hardly be distinguished 
in normally treated sections. Even in these cases they were easily demonstrated with the immunoperoxidase methods. In Case 1, only cyst stages were observed, while in Cases 2, 4 and 5 , both endozoites and cyst stages occurred. The cystozoites (bradyzoites) were stained less strongly than the endozoites (Fig. 3). Extended incubation with primary antibody increased the intensity of staining only moderately. Usually, there was some staining of the cyst wall. In the dog (Case 3), neither endozoites nor cystozoites were stained.

Encephalitozoon-like parasites. In all cases of suspected encephalitozoonosis, parasitic organisms resembling spores were stained distinctly when anti-Encephalitozoon serum was used (Figs. 4, 5 and 6). Whether proliferative stages also were stained, could not be determined. In addition, there was a distinct reaction along the membrane of the parasitophorous vacuole (Figs. 4 and 6 ). No reaction was observed using normal rabbit serum, or anti-Toxoplasma serum as primary antiserum. Most spores that could be distinguished in the cytoplasm of macrophages, appeared to be stained (Fig. 5). This was in con-

F i g u r e 1. Scattered endozoites (tachyzoites) of $\mathrm{T}$. gondii, reacting with anti-Toxoplasma serum; mouse liver (control case). ABC technique; counterstained with hematoxylin. $\times 400$.

Figure 2. Parasitophorous vacuole containing endozoites of $T$. gondii, reacting with anti-Toxoplasma serum; liver of a mouse (control case). ABC technique; counterstained with hematoxylin. $\times 1,700$. Fig u r e 3. Cyst stage reacting with anti-Toxoplasma serum; brain of a cat (Case 1). Note the less intense staining of the cystozoites compared with the endozoites in Figs. 1 and 2. ABC technique; counterstained with hematoxylin. $\times 700$.

Figure 4. Parasitophorous vacuole with parasites reacting with anti-Encephalitozoon serum; kidney of a blue fox (Case 14). Note the strong reaction outlining the membrane of the parasitophorous vacuole. $A B C$ technique; counterstained with hematoxylin. $\times 700$.

Figure 5. Numerous phagocytized parasites reacting fith antiEncephalitozoon serum; brain granuloma of a blue fox (Case 13). ABC technique; counterstained with hematoxylin. $\times 700$.

Figure 6. Parasitophorous vacuole with parasites reacting with anti-Encephalitozoon serum; kidney of a blue fox (Case 14). A few spores are also seen in the tubular lumen (arrow). ABC technique; counterstained with hematoxylin. $\times 1,700$. 


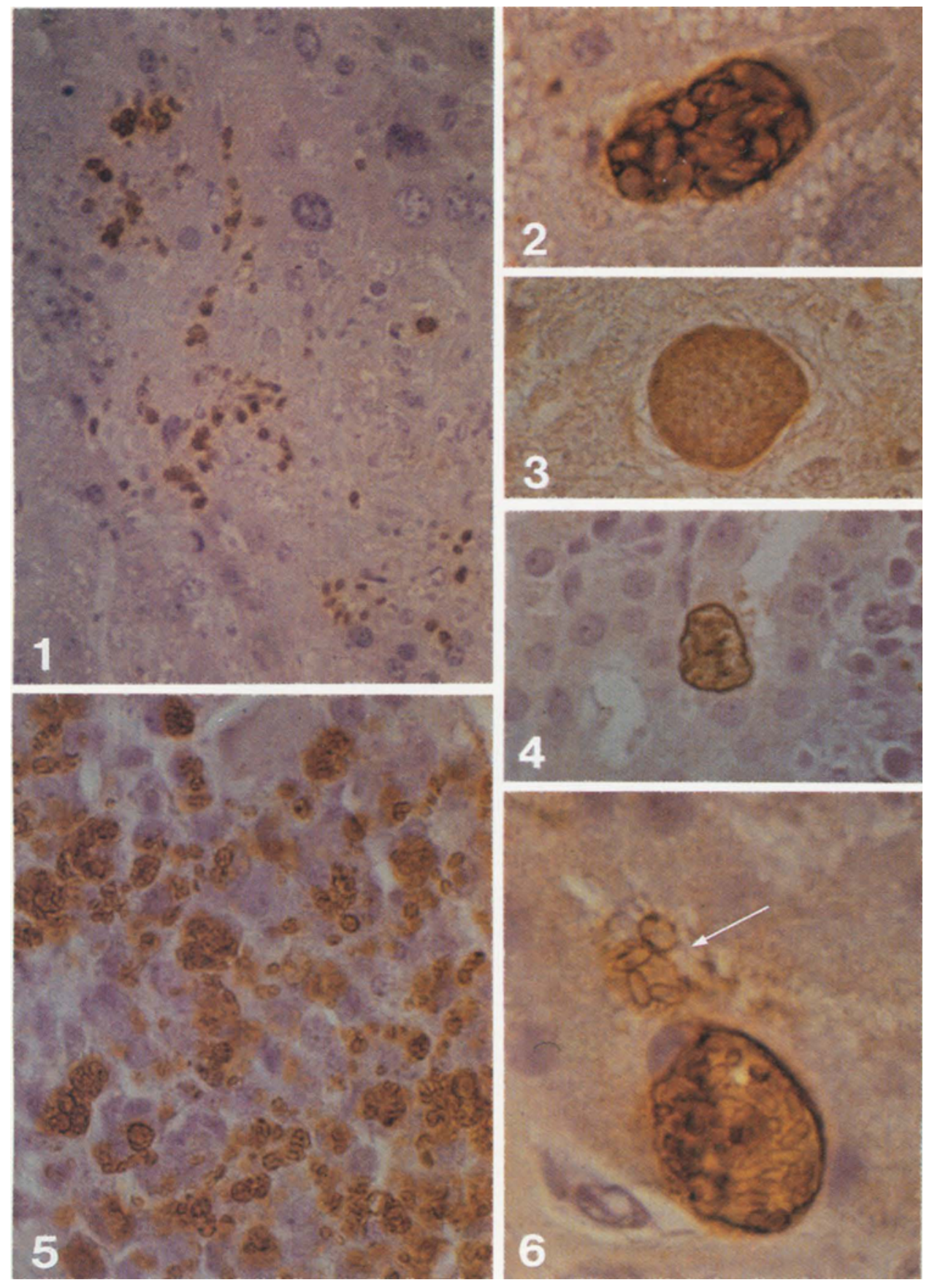




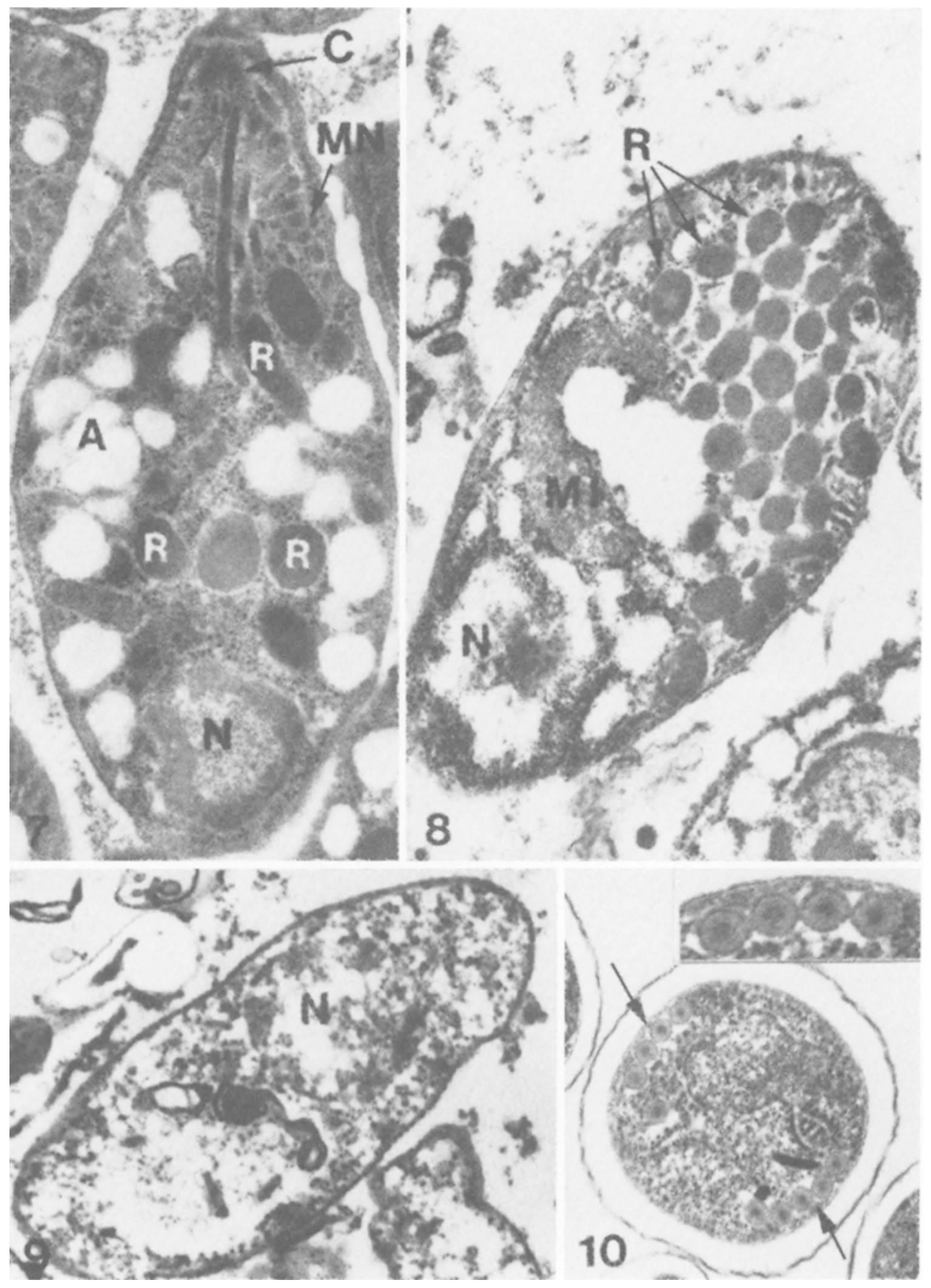


trast to the many unstained spores occurring in sections stained by the modified Gram method. In the sections from the rabbit (Case 18), there was no definite increase in the intensity of background staining, although antibodies against rabbit immunoglobulins were used as secondary antibody.

\section{Ultrastructural studies}

Tox oplasma-like parasites. In contrast to the surrounding host tissue, the fine structures of the parasites were comparatively well preserved in most cases. In all cases but the $\mathrm{dog}$, the fine structures were consistent with those of merozoites of T.gondii (Fig. 7). The nucleus, conoid, rhoptries, and the vacuoles of the amylopectin granules could be distinguished even in necrotic merozoites. The mitochondrion was usually less distinct. The subpellicular microtubules and the micronemes were fairly well preserved in most cases, but could hardly be distinguished in some of the hares. Division by endodyogeny was observed in several cases.

The parasites seen in the cats and hares had no more than 9 rhoptries, while the parasite in the dog (Case 3) frequently had 11, and sometimes more than 20, rhoptries (Fig. 8). In addition, this parasite contained only few amylopectin granules.

Encephalitozoon-like parasites. Both spores and proliferative stages of the parasites were studied. The spores

Figure 7. Electron micrograph of a cystozoite with fine structures consistent with $\mathrm{T}$. gondii; myocardium of a cat (Case 2). A, amylopectin granules; $\mathrm{C}$, conoid; $\mathrm{MN}$, micronemes; $\mathrm{N}$, nucleus; R, rhoptries. $\times 30,000$.

Figure 8. Electron micrograph of an endozoite that is different from merozoites of $T$. gondii; spinal cord of a dog (Case 3). Note the numerous rhoptries (R). MI, mitochondrion; N, nucleus. The section does not include the anterior end of the parasite. $\times 30.000$,

Figure 9. Electron micrograph of a microsporidian sporont in a parasitophorous vacuole; brain tissue of a blue fox (Case 13). Note the single nucleus $(\mathrm{N})$. The absence of diplocarya in the developmental cycle suggests Encephalitozoon. $\times 25,000$.

Figure 10 . Electron micrograph of a typical microsporidian spore in a renal tubular cell of a blue fox (Case 14). Note the coiled filament (arrows). $\times 39,000$. Inset: Higher magnification of the coiled filament. $\times 70,500$. 
and sporoblasts were well preserved. A coiled filament could be distinguished in many of these (Fig. 10). The schizonts and sporonts were apparently very brittle structures, and many were so poorly preserved that no organelles could be distinguished. However, in some, a single nucleus could be observed (Fig. 9).

\section{DISCUSSION}

The immunoperoxidase methods appear to be very useful in demonstrating protozoa in histologic sections. In the present cases, the morphology of the parasite was so excellently demonstrated that any confusion with non-specifically stained structures appears inconceivable.

Though the ABC method had a higher sensitivity than the PAP method, the specificity was not essentially better at optimal dilutions of the primary antisera. The specificity will of course depend on the specificity of the antiserum which might contain antibodies against other agents, or the specific antibodies might cross-react with other parasites. Concerning T. gondii antibodies, cross-reaction with Hammondia spp. must be expected. Animals infected with $\mathrm{H}$. hammondi develop antibodies against $\mathrm{T}$. gondii (Christie \& Dubey 1977). Araujo et al. (1984) found antigenic similarity between these two parasites. Likewise, Hammondia can probably not be differed from $T$. gondii on the basis of ultrastructural criteria. However, the pathogenicity of Hammondia is probably very modest (Dubey 1977). Whether there is crossimmunity between $\mathrm{E}$. cuniculi and other parasites, is not known. However, nearly all mammalian microsporidian pathogens so far investigated, appear to belong to the genus Encephalitozoon. In addition, it seems likely that only one species is involved (Montrey et al. 1973, Barker 1975, Pakes et al. 1975, Shadduck et al. 1978, Botha et al. 1979, Mohn et al. 1981).

The less intense staining of the cystozoites compared with the endozoites of $\mathrm{T}$. gondii, may be due to antigenic differences. Lunde \& Jacobs (1983) found that antisera against endozoites of $\mathbf{T}$. gondii reacted only partially with cystozoites, while antisera against cystozoites did not cross-react at all with endozoites. Hyperimmune sera made by inoculation of endozoites alone may contain antibodies almost exclusively against endozoites, since the antigens of the later developing cystozoites may not be accessible to the immune system because of sequestration inside 
the cyst wall. Another reason for the different reactions may be that because the cystozoites are tightly packed and surrounded by a dense material, the antigens are rendered less available for antibodies in the immunological tests.

The positive staining along the membrane of the parasitophorous vacuoles both of $T$. gondii and $E$. cuniculi, and the cyst wall of $T$. gondii, could suggest the presence of antigenic deposits derived from the parasites. The cyst wall of $\mathrm{T}$. gondii is thought to be formed by deposition of material from the parasites on the membrane of the parasitophorous vacuole (Jacobs \& Frenkel 1982), and might therefore contain parasitic antigens.

The immunoperoxidase methods appeared particularly useful in demonstrating parasites in autolytic tissue containing only endozoites of T. gondii. Such parasites are extremely difficult to detect in routine sections. In the cases of encephalitozoonosis, the immunoperoxidase methods must be regarded as more specific than the modified Gram method. In addition, phagocytized and probably partly degraded spores were stained to a greater extent with the immunoperoxidase methods.

The negative result of the immunoperoxidase test on the parasite in the dog (Case 3 ), is in agreement with the ultrastructural findings, suggesting that this parasite is identical with the cyst-forming sporozoon found in Boxer dogs by Bjerkås et al. (1984). Nor did this parasite react positively with antiToxoplasma serum (unpublished).

All stages of the life cycle of Encephalitozoon contain only one single nucleus, and multiplicate within a parasitophorous vacuole of the host cell, in contrast to the parasites within the genus Nosema (Cali 1970). However, in the present cases, the proliferative stages were often insufficiently preserved for finestructural analysis. On the other hand, the occurrence of typical microsporidian spores must be regarded as a fairly reliable criterion for diagnosis, since nearly all mammalian microsporidian pathogens so far investigated, are probably identical to E. cuniculi (Montrey et al. 1973, Barker 1975, Pakes et al. 1975, Shadduck et al. 1978, Botha et al. 1979, Mohn et al. 1981).

Paraffin blocks that had been stored for several years were still suitable for both electron microscopic and immunoperoxidase studies. These observations mean that it is possible to do ultrastructural in addition to immunohistochemical studies in most cases, even if there are few parasites present in the 
tissue. Areas with parasites and/or lesions can be cut out from corresponding areas in the paraffin block, thus increasing the chance of detecting parasites.

\section{REFERENCES}

Andres, T. L., S. A. Dorman, W. C. Winn, T. D. Trainer \& D. P. Perl: Immunohistochemical demonstration of Toxoplasma gondii. Amer. J. clin. Path. 1981, 75, 431-434.

Araujo, F. G., J. P. Dubey \& J. S. Remington: Antigenic similarity between the coccidian parasites Toxoplasma gondii and Hammondia hammondi. J. Protozool. 1984, 31, 145-147.

Barker, R. J.: Ultrastructural observations on Encephalitozoon cuniculi Levaditi, Nicolau et Schoen, 1923, from mouse peritoneal macrophages. Folia Parasit. (Praha) 1975, 22, 1-9.

Bjerkås, I., S. F. Mohn \& J. Presthus: Unidentified cystforming Sporozoon causing encephalomyelitis and myositis in dogs. Z. Parasitenk. 1984, 70, 271-274.

Botha, W. S., A. F. Van Dellen \& C. G. Stewart: Canine encephalitozoonosis in South Africa. J. S. Afr. vet. med. Ass. 1979, 50, 135144.

Cali, A.: Morphogenesis in the genus Nosema. Proc. 4th Int. Colloquium Insect. Path., Maryland 1970, pp. 431-438.

Cristie, E. \& J. P. Dubey: Cross-immunity between Hammondia and Toxoplasma infections in mice and hamsters. Infect. Immun. 1977, 18, 412-415.

Dubey, J. P.: Toxoplasma, Hammondia, Besnoitia, Sarcocystis and other tissue cyst-forming coccidia of man and animals. In: Kreier, J. P. (ed.). Parasitic Protozoa Vol. III. Academic Press, New York, San Francisco, London 1977, pp. 101-238.

Dutton, G. N., J. Hay \& J. Ralston: The immunocytochemical demonstration of Toxoplasma within the eyes of congenitally infected mice. Ann. trop. Med. Parasit. 1984, 78, 431-433.

Guesdon, J.-L., T. Ternynck \& S. Avrameas: The use of avidin-biotin interaction in immunoenzymatic techniques. J. Histochem. Cytochem. 1979, 27, 1131-1139.

Hsu, S.-M., L. Raine \& H. Fanger: A comparative study of the peroxidase-antiperoxidase method and an avidin-biotin complex method for studying polypeptide hormones with radioimmunoassay antibodies. Amer. J. clin. Path. 1981, 75, 734—738.

Jacobs, L. \& J. K. Frenkel: Toxoplasmosis. In: Steele, J. H. (ed.). Parasitic Zoonoses Vol. I. CRC Press, Boca Raton, Florida 1982, pp. 167-185.

Lunde, M. N. \& L. Jacobs: Antigenic differences between endozoites and cystozoites of Toxoplasma gondii. J. Parasit. 1983, 69, 806 -808 . 
Mohn, S. F., T. Landsverk \& K. Nordstoga: Encephalitozoonosis in the blue fox - Morphological identification of the parasite. Acta path. microbiol. scand. Sect. B. 1981, 89, 117-122.

Montrey, R. D., J. A. Shadduck \& S. P. Pakes: In vitro study of host range of three isolates of Encephalitozoon (Nosema). J. infect. Dis. 1973, 127, 450—454.

Pakes, S. P., J. A. Schadduck \& A. Cali: Fine structure of Encephalitozoon cuniculi from rabbits, mice and hamsters. J. Protozool. $1975,22,481-488$.

Petri, M.: Studies on Nosema cuniculi found in transplantable ascites tumours with a survey of microsporidiosis in mammals. Acta path. microbiol. scand. 1969, Suppl. 204.

Scholtyseck, E. \& H. Mehlhorn: Ultrastructural study of characteristic organelles (paired organelles, micronemes, micropores) of Sporozoa and related organisms. Z. Parasitenk. 1970, 34, 97127.

Shadduck, J. A., R. Bendele \& G. T. Robinson: Isolation of the causative organism of canine encephalitozoonosis. Vet. Path. 1978, $15,449-460$.

Sternberger, L. A., P. H. Hardy, J. J. Cuculis \& H. G. Meyer: The unlabelled antibody enzyme method of immunohistochemistry. Preparation and properties of soluable antigen-antibody complex (horseradish peroxidase-antihorseradish peroxidase) and its use in identification of spirochetes. J. Histochem. Cytochem. $1970,18,315-333$.

Sulzer, A. J., E. Scholtyseck, C. Callaway, M. T. Smith \& T. W. Huber: Diagnosis of toxoplasmosis by electron microscopic finestructural analysis. Amer. J. clin. Path. 1979, 72, 225-229.

Wood, G. S. \& R. Warnke: Suppression of endogenous avidin-binding activity in tissues and its relevance to biotin-avidin detection systems. J. Histochem. Cytochem. 1981, 29, 1196-1204.

\section{SAMMENDRAG}

Identifisering av Toxoplasma gondii og Encephalitozoon cuniculi ved hjelp av immunoperoksydase-teknikk og elektronmikroskopi $i$ lagret, formalin-fiksert, parafin-innst $\phi$ pt vevsmateriale.

Peroksydase-antiperoksydase- (PAP) og avidin-biotin-kompleksteknikk (ABC) ble benyttet til å identifisere protozoer i formalinfiksert materiale. Materialet besto av parafinblokker fra 18 kasus hvor det var mistanke om toxoplasmose eller encephalitozoonose. Enkelte blokker hadde vært lagret så lenge som 18 år. ABC-metoden var mer sensitiv enn PAP-metoden, men ved passende fortynning av primært antistoff ble det tydelig reaksjon ved begge metodene. Materialets alder syntes ikke å påvirke resultatet. Fagocytterte og nekrotiske parasitter ble også ofte farget. Cystozoitter (bradyzoitter) av T. gondii ble farget svakere enn endozoitter (tachyzoitter). En Toxoplasma-lignende parasitt fra hund reagerte ikke med anti-Toxoplasma serum. Elektron- 
mikroskopisk unders $\varnothing$ kelse tydet imidlertid på at den var identisk med en cyste-dannende sporozo som er beskrevet tidligere hos hund. Elektronmikroskopi basert på parafin-innst $\varnothing$ pt materiale ser ut til å være en egnet metode for identifisering av protozoer og representerer således et supplement eller alternativ til immunoperoksydase-teknikkene.

(Received October 2, 1985).

Reprints may be requested from: I. Bjerkås, the Department of Pathology, Norwegian College of Veterinary Medicine, P. O. Box 8146, Dep., 0033 Oslo 1, Norway. 